\title{
Prognostic usefulness of some parameters in dogs with canine parvovirus"
}

\author{
Idil BASTAN ${ }^{1}$, Arif KURTDEDE ${ }^{1}$, Doğukan ÖZEN ${ }^{2}$ \\ ${ }^{1}$ Department of Internal Medicine, Faculty of Veterinary Medicine, Ankara University; ${ }^{2}$ Department of Biostatistics, Faculty of \\ Veterinary Medicine, Ankara University, Ankara, Turkey.
}

Summary: The purpose of this study was to evaluate the prognostic usefulness of some parameters in dogs with canine parvovirus (CPV). Fifty-nine animals which consist of 39 ill and 20 healthy puppies were used in the study. All puppies were underwent a complete physical examination and laboratory variables (CBC, serum routine biochemistry profile, cTn-I, TNF- $\alpha$ ) on their first admission to clinic and on following every day before treatment until discharge or death. Despite aggressive treatment with available therapy, 14 of 39 dogs died. Non-survivor dogs had significantly lower leukocyte, lymphocyte, monocyte and granulocyte counts but had significantly higher serum urea and creatinine concentrations than those of survivor dogs at presentation ( $<<0.05$ ). Serum cTn-I concentration level were positive in 11 of 14 non-survival dogs and negative in all of the survival dogs. The relative risk of death for the dogs with TNF- $\alpha$ positive was 3,39 times (95\% CI:1,53-7,52) higher than that of dogs with TNF- $\alpha$ negative. This study demonstrates that leukocyte, lymphocyte, granulocyte, monocyte counts, serum urea and creatinine concentrations, cTn-I and TNF- $\alpha$ levels are useful parameters for predicting the prognosis of dogs with CPV.

Key words: Canine parvovirus, cTn-I, prognosis, TNF- $\alpha$.

\section{Kanin parvoviruslu köpeklerde bazı parametrelerin prognostik kullanımları}

Özet: Bu çalışmanın amacı kanin parvoviruslu köpeklerde (CPV) prognostik yararı olan bazı parametlerin değerlendirilmesidir. Bu çalışmada 39'u hasta, 20'si sağliklı olmak üzere toplam 59 köpek kullanıldı. Bütün köpeklerin fiziksel muayene ve laboratuar (CBC, serum routine biochemistry profile, cTn-I, TNF- $\alpha$ ) verileri kayıt altına alındı. Uygulanan agresif tedaviye rağmen 39 köpeğin 14'ü öldü. Ölen köpeklerde lökosit, lenfosit, monosit ve granülosit sayısı önemli derecede düşük; üre ve kreatinin konsantrasyonu ise iyileşen köpeklere oranla önemli derecede yüksek bulundu $(\mathrm{p}<0.05)$. Serum cTn-I konsantrasyonu, ölen 14 köpeğin 11 'inde pozitif, iyileşen köpeklerin tamamında negatif bulundu. TNF- $\alpha$ pozitif olan köpeklerin ölme olasılığının iyileşenlere göre 3,39 kat daha fazla olduğu saptandı (95\% CI:1,53-7,52). Bu çalışma; lökosit, lenfosit, granülosit, monosit sayılarının; serum üre ve kreatinin konsantrasyonlarının; cTn-I ve TNF- $\alpha$ değerlerinin, CPV'li köpeklerde prognozun belirlenmesinde önemli parametreler olduğunu gösterdi.

Anahtar sözcükler: cTn-I, kanin parvovirus, prognosis, TNF- $\alpha$

\section{Introduction}

Canine parvovirus (CPV) infection is one of the common causes of mortality in puppies younger than 6 months old $(2,18)$. Despite aggressive treatment with available therapies, many dogs still died because of CPVrelated complications $(4,6,21,34,35)$. Mortality rates vary between 4 and 40 per cent (29).

Canine parvovirus (Parvoviridae type $2 \mathrm{a}$ and $2 \mathrm{~b}$ ) has a predilection to infect rapidly dividing cells of the gastrointestinal tract, lymphoid tissue, and bone marrow, leading to hemorrhagic diarrhea, vomiting, marked leukopenia, and immunosuppression (8). Bacteriemia leads to sepsis in dogs with immunosuppression $(4,6,16$, $25,29,37)$. CPV-2 myocarditis is very rare and may develop secondarily due to the sepsis with parvoviral enteritis $(1,3,36)$.

The aim of this study was to evaluate the prognostic usefulness of some parameters in naturally $\mathrm{CPV}$ infected dogs.

\section{Materials and Methods}

Animals and clinical diagnosis: This prospective study was performed on 59 puppies, 39 with CPV as study group and 20 healthy dogs as control group. Puppies with CPV were composed of various breeds (11 mixed breeds, 8 Anatolian shepherd, 2 Husky, 2 Cocker, 1 Terrier, 5 Pointer, 2 Golden Retriver and 8 German shepherd), sex (22 males and 17 females), ages (mean

\footnotetext{
* This study is summarized from the PhD dissertation of the first author.
} 
$7,54 \pm 0,32$ weeks), and weights (mean $4,28 \pm 0,48 \mathrm{~kg}$ ). Healthy puppies were consisted of various breeds (8 Anatolian shepherd, 5 Golden Retriver, 3 Rottweiler, 3 German shepherd and 1 mixed breeds) and either sex (12 males and 8 females). Mean age was 9,4 $\pm 0,27$ weeks. Mean body weight was $3,39 \pm 0,25 \mathrm{~kg}$. They were admitted to the Small Animal Clinic of Internal Medicine, Faculty of Veterinary Medicine at Ankara University. The ages of the puppies were between 4 and 12 weeks old, of any breed and either sex, and exhibited one or more of clinical signs typical of CPV infection (eg, lethargy, anorexia, vomiting, hemorrhagic diarrhea, dehydration, collapse).

Laboratory diagnosis: The diagnosis of $\mathrm{CPV}$ was performed with a PCR method described by Ozkul et al. (27). According to method, a fecal specimen was collected by rectal swabbing in order to detect DNA of CPV. A swab sample was immediately immersed into $500 \mu \mathrm{l}$ of TE buffer $(10 \mathrm{mM}$ Tris-HCl, $\mathrm{pH} 7.8 ; 1 \mathrm{mM}$ EDTA) and transported to the laboratory. CPV DNA was extracted using a Phenol/Choloroform/Isoamylalchol $(25: 24: 1, \mathrm{v} / \mathrm{v} / \mathrm{v})$ mixture in an equal volume $(400 \mu \mathrm{l})$ of the sample used. DNA extraction was repeated at least twice until the interphase was completely cleared after brief spinning at $6000 \mathrm{rpm}$ for $5 \mathrm{~min}$. The DNA was then precipitated by adding an equal volume of isopropanol in the presence of a $1 / 10$ volume of $3 \mathrm{M}$ Na-Acetate $(\mathrm{pH}$ 5.2) at $-80{ }^{\circ} \mathrm{C}$ for $1 \mathrm{~h}$. The total DNA was isolated by centrifugation at $12,000 \mathrm{rpm}$ for $10 \mathrm{~min}$, which was followed by washing the pellet with $70 \%$ ethanol and subsequent drying at $37{ }^{\circ} \mathrm{C}$. The DNA was dissolved in $20 \mu \mathrm{l}$ of sterile distilled water and used for PCR amplification. or this purpose, the complete VP1-VP2 coding genome region of CPV DNA was target. The PCR amplification was performed in a total of $30 \mu \mathrm{l}$ by adding $3 \mu \mathrm{l}$ of DNA extracted to the PCR master mix containing $75 \mathrm{mM}$ Tris- $\mathrm{HCl}(\mathrm{pH}$ 8.8), $20 \mathrm{mM}$ $\mathrm{NH}_{4}\left(\mathrm{SO}_{4}\right)_{2}, 1.5 \mathrm{mM}$ of $\mathrm{MgCl}_{2}, 10$ pmole of each primer, $0.2 \mathrm{mM}$ of dNTP, and $0.5 \mathrm{U}$ of Taq DNA polymerase (MBI, Fermentas, Lithuania) in a final volume of $30 \mu \mathrm{l}$. The thermal cycler (Techne, Oxford, UK) program was set up as follows: an initial denaturation step at $94{ }^{\circ} \mathrm{C}$ for 6 min was followed by a cycle of $60 \mathrm{~s}$ at $52{ }^{\circ} \mathrm{C}, 150 \mathrm{~s}$ at $72{ }^{\circ} \mathrm{C}$ and $60 \mathrm{~s}$ at $94{ }^{\circ} \mathrm{C}$, repeated 40 times. Amplification was terminated by a final extension at $70{ }^{\circ} \mathrm{C}$ for $10 \mathrm{~min}$. At the end of the reaction, it was expected to amplify a 2245 bp DNA product. During the synthetic amplification of the VP1-VP2 coding region of CPV, attenuated live CPV vaccine virus (Parvoid 2, Solvay Anim. Health, Inc., MN, USA) was used as a standard positive control. The resulting DNA products (amplicons) were separated on $1.5 \%$ agarose gels containing $25 \mu \mathrm{g}$ ethidium bromide after electrophoresis at $80 \mathrm{~V}$ for $30 \mathrm{~min}$. The DNA bands were observed under
UV light and photographic records were made. For RFLP analysis, the PCR products were digested using Apa LI and EcoRV at $37^{\circ} \mathrm{C}$ for $1 \mathrm{~h}$. Samples were then analyzed on $1.7 \%$ agarose gels to determine the cleavage patterns of the amplicons.

Medical Treatment: The puppies were treated with a standard protocol including continuous intravenous (IV) crystalloids (Lactated Ringers) supplemented with potassium chloride, dextrose $5 \%$, amino acid solution, metoclopramide IV bolus every $6-8 \mathrm{~h}(0.2 \mathrm{mg} / \mathrm{kg})$, and ampicillin IV every $8 \mathrm{~h}(15 \mathrm{mg} / \mathrm{kg})$, were administered.

Study Design: Each puppy (study and control group) was subjected to a full physical examination, $\mathrm{CBC}$, routine serum chemistry, cardiac troponin I (cTn-I) and tumor necrosis factor- $\alpha$ (TNF- $\alpha)$ at admission and on following every day (ill puppies only) until the death or discharging. These parameters were used for their ability to predict the prognosis of ill puppies. Blood samples were collected from the cephalic or jugular vein.

Assays: Blood analyses were performed by an automatic cell counter (ABAKUS, China) for $\mathrm{CBC}$ and by automated clinical chemistry analyzer (ERBA, Mannheim, Germany, XL, 600) for chemical analyses using commercially available kits of the manufacturer . CTn-I ELISA kit (Life Diagnostic, Inc, PA, USA., 2010$3-\mathrm{HS}$ ) and canine TNF- $\alpha$ immunoassay (Quantikine, CAT A00) used for the analysis. The cTn-I concentration which is lower than $0,156 \mathrm{ng} / \mathrm{ml}$ (cut-off) was considered as negative. The TNF- $\alpha$ concentration which is lower than $0,9 \mathrm{ng} / \mathrm{ml}$ (cut-off) was considered as negative.

Statistical Analysis: Before performing the statistical analysis, data were examined with ShapiroWilk test for normality and Levene test for homogeneity of variances as parametric test assumptions. Descriptive statistics for each variable were calculated and presented as "Mean \pm Standard Error of Mean". Student t test was used to evaluate the difference between study and control group according to age and weight. One way ANOVA and Kruskal Wallis analysis were used to evaluate the difference between non-survivors, survivors and control groups for the $\mathrm{CBC}$ variables. Duncan test and multiple Mann Whitney U tests with Bonferroni correction were used as post Hoc tests for the $\mathrm{CBC}$ variables that were found statistically significant. Pearson Chi-square was used to evaluate the difference between study and control group for gender. Fisher exact test was used to compare the frequency of being positive or negative for TNF- $\alpha$ levels between study and control group after dichotomizing the counts using cut-off values mentioned. Kaplan- Meier analysis was used to calculate the survival probability for the dogs with CPV on each day. For all comparisons, differences were considered with a minimum of 0.05 significance level. All statistical analysis were performed by using SPPS ${ }^{\circledR} 14.1$ for Windows. 
Table 1 : Haematological parameters in non-survival, survival puppies with CPV and healthy dogs, at the day of admission. Tablo 1 : Ölen, yaşayan ve sağlıklı köpeklerden kliniğe kabul edildikleri gün elde edilen hematolojik parametreler.

\begin{tabular}{|c|c|c|c|}
\hline Parameters & Nonsurvival (n:14) & $\begin{array}{c}\text { Survival } \\
(\mathrm{n}: 25)\end{array}$ & $\begin{array}{l}\text { Healthy } \\
(\mathrm{n}: 20)\end{array}$ \\
\hline WBC $\left(x 10^{3} / \mu \mathrm{L}\right)$ & $2,50 \pm 1,14^{\mathrm{a}}$ & $8,19 \pm 1,50^{b}$ & $11,02 \pm 0,5^{\mathrm{c}}$ \\
\hline $\mathrm{LYM}\left(\mathrm{x} 10^{3} / \mu \mathrm{L}\right)$ & $0,66 \pm 0,14^{\mathrm{a}}$ & $2,38 \pm 0,47^{b}$ & $4,95 \pm 0,24^{c}$ \\
\hline $\operatorname{MONO}\left(\times 10^{3} / \mu \mathrm{L}\right)$ & $0,12 \pm 0,06^{\mathrm{a}}$ & $0,36 \pm 0,09^{\mathrm{b}}$ & $0,41 \pm 0,06^{\mathrm{b}}$ \\
\hline $\operatorname{Gra}\left(\mathrm{x} 10^{3} / \mu \mathrm{L}\right)$ & $1,77 \pm 1,02^{\mathrm{a}}$ & $5,43 \pm 1,09^{b}$ & $5,43 \pm 0,34^{\mathrm{b}}$ \\
\hline $\mathrm{RBC}\left(\times 10^{6} / \mu \mathrm{L}\right)$ & $5,71 \pm 0,42^{\mathrm{a}}$ & $4,96 \pm 0,18^{\mathrm{a}}$ & $4,15 \pm 0,17^{\mathrm{b}}$ \\
\hline HGB (g/dl) & $10,73 \pm 0,42^{\mathrm{a}, \mathrm{b}}$ & $10,20 \pm 0,51^{\mathrm{a}}$ & $8,52 \pm 0,4^{b}$ \\
\hline HCT (\%) & $33,63 \pm 2,41^{\mathrm{a}}$ & $30,48 \pm 1,37^{\mathrm{a}, \mathrm{b}}$ & $25,59 \pm 0,94^{\mathrm{b}}$ \\
\hline $\operatorname{PLT}\left(\mathrm{x} 10^{3} / \mu \mathrm{L}\right)$ & $566,50 \pm 70,14^{\mathrm{a}}$ & $626,04 \pm 55,61^{\mathrm{a}}$ & $416,50 \pm 51,44^{\mathrm{a}}$ \\
\hline RDW (\%) & $18,71 \pm 0,88^{\mathrm{a}}$ & $19,46 \pm 0,60^{\mathrm{a}}$ & $18,4 \pm 0,49^{\text {a }}$ \\
\hline MCV (fL) & $59,50 \pm 1,07^{\mathrm{a}}$ & $60,92 \pm 1,23^{a}$ & $62,93 \pm 1,34^{\mathrm{a}}$ \\
\hline $\mathrm{MCHC}(\mathrm{g} / \mathrm{dL})$ & $32,55 \pm 0,82^{\mathrm{a}}$ & $33,57 \pm 0,46^{\mathrm{a}}$ & $32,84 \pm 0,43^{\mathrm{a}}$ \\
\hline
\end{tabular}

$\overline{a, b, c:}$ Different letters within the same line are significantly different $(p<0.05)$



Figure 1 : Blood leukocyte, lymphocyte, neutrophil, monocyte changes from the first day until 8 days of postadmission in survival dogs.

Şekil 1: Yaşayan köpeklerde uygulama sonras1 1. günden 8. güne kadar kan lökosit, lenfosit, nötrofil, monosit değişiklikleri

\section{Results}

The cardinal clinical signs in the puppies with CPV were anorexia, lethargy, bloody diarrhea, vomiting, moderate or severe dehydration, tachycardia, hypothermia.

Of the 14 non-survived puppies with CPV, 6 died on the first day, 4 died the second day, 3 died the third day, 1 died on the fourth day. Survival probability of the puppies with CPV were found to be on 1 th day as $74,4 \%$, on 2 nd day as $69,2 \%$, on 3rd day as $66,7 \%$.

There were no statistically significant differences in age, bodyweight and gender between the healthy and ill puppies $(\mathrm{p}>0,05)$.

At the day of admission, the mean leukocyte (WBC), lymphocyte (LYM) values of ill puppies were lower than those of healthy dogs $(p<0,05)$. The mean

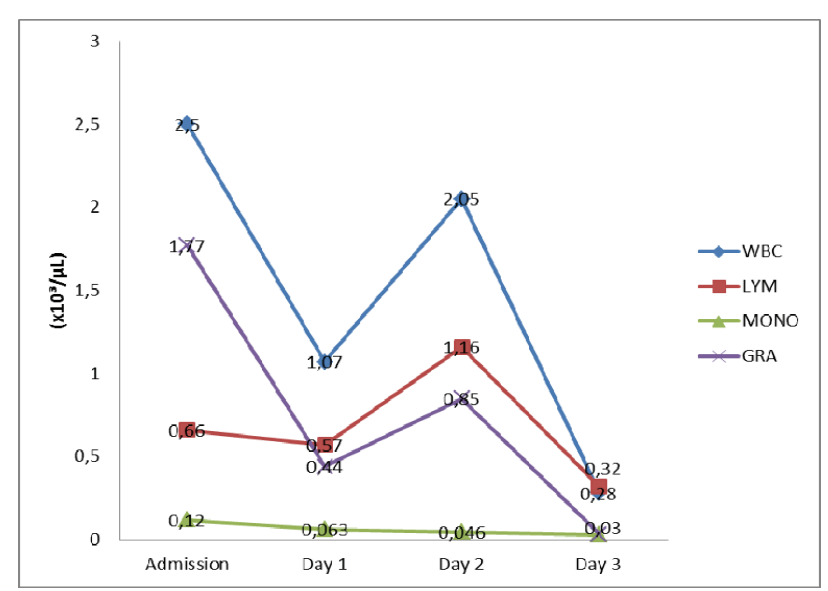

Figure 2 : Blood leukocyte, lymphocyte, neutrophil, monocyte changes from the first day until 8 days of postadmission in nonsurvival dogs.

Şekil 2 : Ölen köpeklerde uygulama sonrası 1. günden 8. güne kadar kan lökosit, lenfosit, nötrofil, monosit değişiklikleri.

WBC, LYM, MONO, GRA counts of non-survival puppies were lower as compared with survival and healthy dogs $(\mathrm{p}<0,05)$ (Table 1$)$. These values decreased within first $24 \mathrm{~h}$ after the admission day and then gradually reached the normal ranges at the end of the eighth day, increasing day by day in survival dogs (Figure 1). On the contrary, in non-survival puppies these values gradually decreased until the day of their death (Figure 2).

Urea and creatinine concentrations were higher in non-survival puppies than survival and healthy dogs at the day of admission $(p<0.05)$ (Table 2$)$. These values reached to normal ranges after treatment was begun in survival puppies. In the contrary, in non-survival puppies creatinine and urea values gradually increased until they 
Table 2 : Chemical and hematological parameters in non-survival and survival puppies with CPV and in healthy dogs at the day of admission.

Tablo 2 : Ölen, yaşayan ve sağlıklı köpeklerden kliniğe kabul edildikleri gün elde edilen kimyasal ve hematolojik parametreler.

\begin{tabular}{lccc}
\hline \multicolumn{1}{c}{ Parameters } & Nonsurvival (n:14) & $\begin{array}{c}\text { Survival } \\
(\mathrm{n}: 25)\end{array}$ & $\begin{array}{c}\text { Healthy } \\
(\mathrm{n}: 20)\end{array}$ \\
\hline Creatinine $(\mathrm{mg} / \mathrm{dl})$ & $0,87 \pm 0,13^{\mathrm{a}}$ & $0,20 \pm 0,03^{\mathrm{b}}$ & $0,39 \pm 0,07^{\mathrm{b}}$ \\
Urea $(\mathrm{mg} / \mathrm{dl})$ & $63,25 \pm 12,9^{\mathrm{a}}$ & $32,15 \pm 4,43^{\mathrm{b}}$ & $21,92 \pm 5,25^{\mathrm{b}}$ \\
Total protein $(\mathrm{g} / \mathrm{dl})$ & $3,61 \pm 0,27^{\mathrm{a}}$ & $3,92 \pm 0,24^{\mathrm{a}}$ & $3,94 \pm 0,16^{\mathrm{a}}$ \\
Albumine $(\mathrm{g} / \mathrm{dl})$ & $2,14 \pm 0,17^{\mathrm{a}}$ & $2,19 \pm 0,09^{\mathrm{a}}$ & $2,57 \pm 0,09^{\mathrm{b}}$ \\
AST (IU/L) & $70,75 \pm 12,88^{\mathrm{a}}$ & $71,75 \pm 10,75^{\mathrm{a}}$ & $40,80 \pm 3,30^{\mathrm{a}}$ \\
LDH (IU/L) & $180,57 \pm 34,40^{\mathrm{a}}$ & $189,10 \pm 32,04^{\mathrm{a}}$ & $130,70 \pm 19,81^{\mathrm{a}}$ \\
\hline a,b,c: Different letters within the same line are significantly different $(p<0.05)$ &
\end{tabular}

died. The cTn-I concentration was positive in eleven of 14 non-survival puppies. They died within 24 hours after detection time of a positive. Mean cTn-I levels were 42,35 $\pm 37,2 \mathrm{ng} / \mathrm{ml}$ (min:0,8, max:451,5, median: 1,52).

Serum TNF- $\alpha$ activity was estimated in three of 25 survival puppies as $7,4 \pm 1,2 \mathrm{pq} / \mathrm{mL}$ and in 8 of 14 nonsurvival puppies as $21,3 \pm 8,2 \mathrm{pq} / \mathrm{mL}$. Frequency of being positive for TNF- $\alpha$ levels were significantly different between survivors and non-survivors with CPV $(\mathrm{p}<0.01)$. Relative risk of death was 3.39 times $(95 \%$ CI:1,53-7,52) higher in TNF- $\alpha$ positive dogs with CPV than survivors with $\mathrm{CPV}$.

\section{Discussion}

Some researchers have found a significant correlation between the degree of leukopenia and prognosis $(24,38)$, while others have not found such a correlation $(10,17)$. In this study, hematological findings including leukopenia, lymphopenia, monocytopenia and granulocytopenia in non-survival puppies were similar to those of previous studies $(8,39)$.

During a systemic response to infection, TNF- $\alpha$ is an early mediator of the pro-inflammatory cascade (22). Several studies have shown a positive correlation between TNF- $\alpha$ level and the severity of sepsis and fatality $(19,20)$. In clinical veterinary medicine, increasing TNF- $\alpha$ activity is a predictor of mortality in naturally occurring canine parvoviral infection (26). In this study, the association between mortality and plasma TNF- $\alpha$ activity was significant in dogs with CPV. Death ratio was 3,39 ( 95\% CI:1,53-7,52) times more TNF- $\alpha$ positive puppies with CPV than survival dogs. So that, TNF- $\alpha$ may be used as a predictor of poor prognosis of CPV.

Elevated serum urea and creatinine are associated with dehydration in puppies with CPV (15). Yilmaz and Senturk (39) found, blood urea nitrogen and creatinine were higher in puppies with CPV than those of healthy dogs. In this study, there were positive correlation between urea and concentrations and increased mortality in non-survival puppies with CPV. These results showed that acute kidney injury developed in non-survival puppies. Kim et al.(12), has stated that acute kidney injury was a serious complication in patients with severe sepsis and septic shock and was associated with significant mortality. Legrand et al.(13), indicated that in animal models, Gram-negative bacterial endotoxemia was associated with renal hypoperfusion and microvascular hypoxia.

In healthy dogs, blood levels of cardiac troponin $\mathrm{T}$ (cTn-T) or cTn-I are very low or below the level of detectability of most assay systems in both humans (11) and animals $(5,9,14,28,32)$. The detection of high concentrations of circulating cTn-I is viewed as a specific indicator of myocardial injury and cellular necrosis (7, 23). Following cardiac injury, troponins are released into the circulation from damaged myocytes. Elevated levels are detectable in the blood within four hours of cardiac damage and reach a peak value within 12 to 24 hours, and then slowly decline over the next five to 20 days, depending on the degree of initial damage $(30,31,33)$. In our study, positive rate of cTn-I level was detected in non-survival dogs. It was understood that death was caused by progressive CPV related myocarditis. These situation shows that myocarditis in dogs with $\mathrm{CPV}$ can be one of the important causes of death and cTn-I may be used more sensitive predictor for mortality than other parameters.

As a result, this study demonstrates that leukocyte, lymphocyte, granulocyte, monocyte counts as well as serum creatinine, urea, cTn-I and TNF- $\alpha$ values at presentation are useful parameters to predict the prognosis of the puppies with CPV.

\section{References}

1. Agungpriyono DR, Uchida K, Tabura H, Yamaguchi R, Tateyama S (1999): Subacute massive necrotizing myocarditis by canine parvovirus type 2 infection with diffuse leukoencephalomalacia in a puppy. Vet Pathol, 36, 77-80.

2. Appel MJ, Scott FW, Carmichael LE (1979): Isolation and immunization studies of a canine parvo-like virus from dogs with hemorrhagic enteritis. Vet Rec, 105, 156-159. 
3. Atwell RB, Kelly WR (2008): Canine parvovirus: a cause of chronic myocardial fibrosis and adolescent congestive heart failure. J Small Anim Pract, 21, 609-620.

4. Cohn LA, Langdon P (2003): Infectious disease. (10941095). In: RV Morgan, R M Bright and M. S. Swartout WB (Ed). Handbook of Small Animal Practice. Saunders. Philadelphia.

5. De Francesco TC, Atkins CE, Keene BW (2002): Prospective clinical evaluation of serum cardiac troponin $T$ in dogs admitted to a veterinary teaching hospital. J Vet Intern Med, 16, 553-557.

6. De Laforcade AM, Freeman LM, Shaw SP, Brooks MB, Rozanski EA, Rush JE. (2003): Hemostatic changes in dogs with naturally occurring sepsis. J Vet Intern Med, 17, 674-679.

7. Fishbein MC, Wang T, Matijasevic M, Hong L, Apple FS (2003): Myocardial tissue troponins $T$ and I. An immunohistochemical study in experimental models of myocardial ischemia. Cardiovasc Pathol, 12, 65-71.

8. Goddard A, Leisewitz MM, Christorher MM, Becker PJ (2008). Prognostic usefulness of blood leucocyte changes in canine parvoviral enteritis. J Vet Intern Med, 22, 309-316.

9. Herndon WE, Kittleson MD, Sanderson K, Drobatz KJ, Clifford CA, Gelzer A, Summerfield NJ, Linde A, Sleeper MM (2002): Cardiac troponin $I$ in feline hypertrophic cardiomyopathy. J Vet Intern Med, 16, 558564.

10. Jacobs, RM, Weiser M, Hall RL (1980): Clinicopathologic features of canine parvoviral enteritis. $\mathrm{J}$ Am Hosp Assoc, 16, 809-814.

11. Jaffe A S, Babuin L, Apple FS (2006): Biomarkers in Acute Cardiac Disease. J Am Coll Cardiol, 48, 1-11.

12. Kim, Y, Huh J W, Lim C, Koh Y, Hong SB (2012): Comparison of acute kidney injury classifications in patients with severe sepsis and septic shock. Am J Med Sci, 12, (Epub ahead of print)

13. Legrand M, Bezemer R, Kandil A, Demirci C, Payen D, Ince C (2011): The role of renal hypoperfusion in development of renal microcirculatory dysfunction in endotoxemic rats. Intensive Care Med, 37, 1534-1542.

14. Lobetti R, Dvir E, Pearson J (2002): Cardiac troponins in canine babesiosis. J Vet Intern Med, 16, 63-68.

15. Macintire DK, Smith-Carr S (1997) Canine parvovirus. Part II. Clinical signs, diagnosis, and treatment. Comp Cont Vet Educ Pract, 19, 291-302.

16. Mantione NL, Otto CM (2005): Characterization of the use of antiemetic agents in dogs with parvoviral enteritis treated at a veterinary teaching hospital: 77 cases (19972000). JAVMA, 227, 1787-1793.

17. Mason MJ, Gillett NA, Buggenburg BA (1987): Clinical, pathological, and epidemiological aspects of canine parvovirus enteritis in an unvaccinated closed beagle colony 1978-1985. J Am Anim Hosp Assoc, 23, 183-192.

18. Mccaw DL, Harrington DP, Jones BD (1996): $A$ retrospective study of canine parvovirus gastroenteritis: 89 cases. J Vet Intern Med, 10, 157.

19. Mira JP, Cariou A, Grall F, Delclaux C, Losser MR, Heshmati F, Cheval C, Monchi M, Teboul JL, Riche F, Leleu G, Arbibe L, Mignon A, Delpech M, Dhainaut JF
(1999): Association of TNF2, a TNF- $\alpha$ promoter polymorphism, with septic shock susceptibility and mortality. JAMA, 282, 561-568.

20. Miyamoto T, Fujinaga T, Yamashita K, Hagio M (1996): Changes of serum cytokine activities and other parameters in dogs with experimentally induced endotoxic shock. Jpn J Vet Res, 44, 107-118.

21. Nappert G, Duphy E, Ruben D, Mann FA (2002): Determination of serum organic acids in puppies with naturally acquired parvoviral enteritis. The Can J Vet Res, 66, 15-18.

22. Nemzek JA, Agrodnia MD, Hauptman JG (2007): Breed specific pro-inflammatory cytokine production as a predisposing factor for susceptibility to sepsis in the dog. $\mathrm{J}$ Vet Emerg Critic Care, 17, 368-372

23. O'Brien PJ (1997): Deficiencies of myocardial troponin-T and creatine kinase $M B$ isoenzyme in dogs with idiopathic dilated cardiomyopathy. Am J Vet Res, 58, 11-16.

24. O'Sullivan G, Durham PJK, Smith JR, Campbell RSF (1984): Experimentally induced severe canine parvoviral enteritis. Aust Vet J, 6, 1-4.

25. Otto C (2007): Sepsis in veterinary patients: what do we know and where can we go? J Vet Emerg Critic Care, 17 (4), 329-332

26. Otto CM, Drobatz KJ, Soter C (1997): Endotoxemia and tumor necrosis factor activity in dogs with naturally occurring parvoviral enteritis. J Vet Intern Med, 11, 6570.

27. Ozkul A, Keles I, Karaoglu T, Çabalar M, Burgu I (2002): Detection and rflp analysis of canine parvovirus (cpv) dna by polymerase chain reaction (pcr) in a dog. Turk J Vet Anim Sci, 6, 1201-1203.

28. Pelander L, Ragnvi H, Haggstrom J (2008): Concentrations of cardiac troponin I before and after ovariohysterectomy in 46 female dogs with pyometra. Acta Vet Scand, 50, 35.

29. Prittie J (2004): Canine parvoviral enteritis: a review of diagnosis, management, and prevention. J Vet Emerg Crit Care, 14, 167-176.

30. Remppis A, Ehlermann P, Giannitsis E (2000): Cardiac troponin $T$ levels at 96 hours reflect myocardial infarct size: a pathoanatomical study. Cardiol, 93, 249-253.

31. Ricchiuti V, Sharkey SW, Murakami MM (1998): Cardiac tro-ponin I and $T$ alterations in dog hearts with myocardial infarction: correlation with infarct size. Am J Clin Pathol, 110, 241-247.

32. Sleeper MM, Clifford CA, Laster LL (2001): Cardiac troponin I in the normal dog and cat. J Vet Intern Med, 15, 501-503.

33. Spratt DP, Mellanby RJ, Drury N, Archer J (2005): Cardiac troponin I: evaluation of a biomarker for the diagnosis of heart disease in the dog. J Small Anim Pract, 46, 139-145.

34. Turk J, Miller M, Brown T, Fales W, Fischer J, Gosser H, Nelson S, Shaw D, Solorzano R (1990): Coliform septicemia and pulmonary disease associat ed with canine parvoviral enteritis: 88cases (1987-1988). JAVMA, 196(5), 771- 773 .

35. Turk J, Fales W, Miller M., Pace L, Fischer J, Johnson G, Kreeger J, Turnquist S, Pittman L, Rottinghaus A 
(1992): Enteric Clostridium perfringens infection associated with parvoviral enteritis in dogs: 74 cases (1987-1990). JAVMA, 200, 991- 994.

36. Van Rensburg IB, Meintjes R (1986): Bacterial myocarditis secondary to parvovirus enteritis in a puppy. JS Afr Vet Assoc, 57, 115-156.

37. Willard MD (2003): Canine parvoviral enteritis. 433-435. In: Nelson RW, Couto CG (Ed) Small Animal Internal Medicine. Mosby Comp. Philadelphia.

38. Woods CB, Pollack RVH, Carmichael LE (1980): Canine parvoviral enteritis. JAAHA, 16, 171-179.
39. Yilmaz Z, Senturk Z (2007): Characterization of lipid profiles in dogs with parvoviral enteritis. J Small Anim Pract, 48, 643-650.

Geliş tarihi: 12.06.2012 / Kabul tarihi: 09.10.2012

\section{Address for correspondence:}

Ídil Baştan, DVM, Ph.D.

Ankara University, Faculty of Veterinary Medicine,

Department of Internal Medicine, 06110 ,

Diskapi, Ankara, Turkey

e-mail: idilbastan@yahoo.com 